\title{
Wpływ procesów denudacji na właściwości osadów wypełniających zagłębienia między krętymi walami z erozji wód subglacjalnych w okolicy Zbójna (Pojezierze Dobrzyńskie)
}

\author{
Effect of denudation processes on properties of sediments filling the intra-glacial \\ curvilineations troughs in Zbójno vicinity (Dobrzyń Lakeland)
}

\author{
Mirosław T. Karasiewicz ${ }^{1}$, Piotr Hulisz ${ }^{2}$, Marcin Świtoniak ${ }^{2}$ \\ ${ }^{1}$ Katedra Geomorfologii i Paleogeografii Czwartorzędu, Uniwersytet Mikołaja Kopernika, Toruń, mtkar@umk.pl \\ ${ }^{2}$ Katedra Gleboznawstwa i Ksztattowania Krajobrazu, Uniwersytet Mikołaja Kopernika, Toruń
}

\begin{abstract}
Zarys treści: Badania prowadzono w obrębie pola testowego o powierzchni $1 \mathrm{~km}^{2} \mathrm{w}$ okolicy Zbójna (Pojezierze Dobrzyńskie). Ich celem była analiza wpływu denudacji (naturalnej i antropogenicznej) na właściwości osadów zagłębień występujących między formami wypukłymi (krętymi wałami z erozji wód subglacjalnych). Wyróżniono pięć typów wypełnień badanych zagłębień. Badania wykazały, że występująca w nich specyficzna sekwencja osadów ma wyraźny związek zarówno z procesami naturalnymi, jak i z intensywną działalnością rolniczą prowadzoną od wieloleci na tym obszarze. Stopień i zasięg przekształceń był w znacznym stopniu uzależniony od cech morfometrycznych tych zagłębień. W porównaniu z osadami budującymi grzbiet krętego wału z erozji wód subglacjalnych, osady analizowanych zagłębień charakteryzowały się wyraźnie odmiennym chemizmem, który niewątpliwie wskazywał na ich funkcjonowanie jako pułapek sedymentacyjnych.
\end{abstract}

Słowa kluczowe: zagłębienia pomiędzy krętymi wałami z erozji wód subglacjalnych, drumliny, procesy stokowe, procesy denudacyjne, użytkowanie rolnicze

\begin{abstract}
The research was conducted within a test field of $1 \mathrm{~km}^{2}$ located near Zbójno, that lies in the south-eastern part of the Dobrzyń Lakeland. The objective of the research was to analyze the effect of natural and anthropogenic denudation on the properties of sediments in depressions between glacial curvilineations. Five types of deposits were identified in the studied depressions. These depressions are filled with sediments sequences which are closely associated with natural processes and long-term extensive farming. The degree and the range of transformations of deposits and depressions depend largely on their morphometric characteristics of these depressions. Compared with sediments building the ridge of a glacial curvilineation, the deposits of the analysed depressions were characterised by significantly different chemical composition, which clearly indicates their function as sediment traps.
\end{abstract}

Key words: intra-glacial curvilineations troughs, drumlins, slope processes, denudation processes, agriculture use

\begin{abstract}
Wstęp
Charakterystycznym elementem rzeźby południowo-wschodniej części Pojezierza Dobrzyńskiego są rozległe baseny glacjalne, w których dominującą formą rzeźby są wały ułożone równolegle względem siebie. Występują one na zapleczu maksymalnego zasięgu subfazy kujawsko-dobrzyńskiej zlodowacenia wisły, w obrębie tzw. chrostkowskiej strefy czołowo-morenowej (Olszewski
\end{abstract}

1997). W jednym $z$ takich basenów, w okolicy wsi Zbójno, znajduje się obszar, który do 2010 r. nazywany był „polem drumlinowym” (ryc. 1).

Pionierskie badania geomorfologiczne na tym terenie prowadził Nechay (1927). Scharakteryzował on morfologię oraz budowę wewnętrzną form wypukłych i nazwał je drumlinami, a także wyróżnił m.in. trzy zespoły tych form (północny, południowy i wschodni) o łącznej powierzchni $32,5 \mathrm{~km}^{2}$. Autor ten opisywał wały drumlinowe 
jako eliptyczne, wydłużone wyniosłości o zaokrąglonym grzbiecie i łagodnie nachylonym stoku. Dalsze, znacznie bardziej szczegółowe badania morfologii oraz budowy wewnętrznej drumlinów, prowadzone głównie w okresie powojennym, wykazały, że w ich formowaniu brały udział złożone, erozyjno-deformacyjno-depozycyjne procesy glacjalne oraz procesy erozji i akumulacji glacjofluwialnej, spowodowane działalnością wód roztopowych w odspojeniach i kanałach subglacjalnych (Jewtuchowicz 1956, Liberacki 1961, Lamparski Z. 1972, 1983, 1991, Rudnicki 1979, Niewiarowski, Wysota 1995, Niewiarowski i in. 1995, Olszewski 1997, 2000a, b, c, 2001a, b, Lamparski P. 2005, Głębicki, Marks 2009). Morfologia i geneza form w okolicy Zbójna była też dyskutowana przez Olszewskiego (2000c). Autor ten rozważał klasyfikację tych form jako drumlinów lub drumlinoidów.

Odmienny pogląd na genezę omawianych wzniesień zaprezentowali Lesemann i in. (2010). Zdaniem tych autorów nie są to drumliny, ale kręte wały z erozji wód subglacjalnych (ang. glacial curvilineations), które zostały utwo-

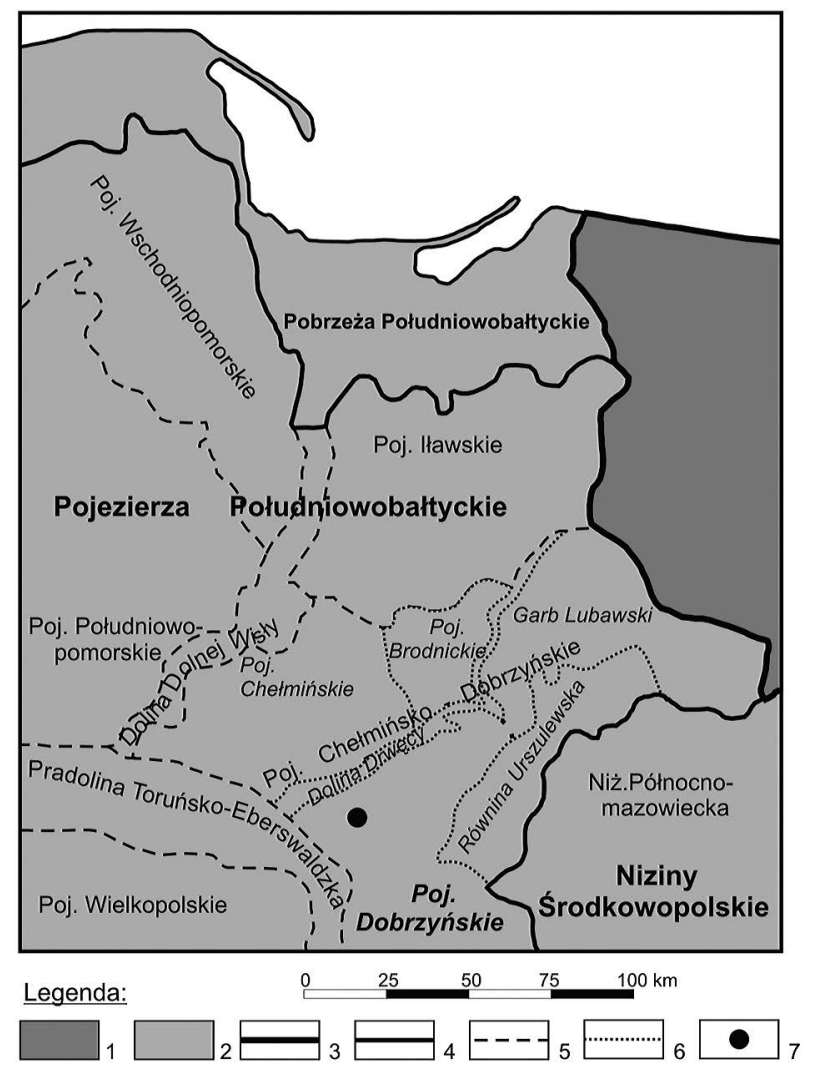

Ryc. 1. Lokalizacja obszaru badań na tle podziału fizycznogeograficznego Polski według Kondrackiego (1998)

1 - Niż Wschodnioeuropejski, 2 - Pozaalpejska Europa Środkowa, 3 granice megaregionów, 4 - granice podprowincji, 5 - granice makroregionów, 6 - granice mezoregionów (w obrębie Pojezierza Chełmińsko-Dobrzyńskiego), 7 - obszar badań

Fig. 1. Location of the study area against a background of the physical and geographical division of Poland (Kondracki 1998)

1 - Eastern European Lowland, 2 - Non-Alpine Central Europe, 3 - boundaries of megaregions, 4 - boundaries of subprovinces, 5 boundaries of macroregions, 6 - boundaries of mesoregions (within the Chełmno-Dobrzyń Lake District), 7 - the study area rzone w warunkach subglacjalnych przez podłużne wiry prądowe wód roztopowych płynących pod lądolodem.

Terminologia dotycząca drumlinów zbójeńskich w świetle najnowszych poglądów podlega ciągłej dyskusji (por. Lesemann i in. 2010). W nawiązaniu do omówionej powyżej literatury dotyczącej obszaru położonego wokół Zbójna, większość badaczy opisywała analizowane formy jako drumliny. Autorzy tej publikacji zgadzają się z koncepcją Lesemanna i in. (2010), uznając, że na tym obszarze występują kręte wały z erozji wód subglacjalnych. Są one rozdzielone obniżeniami typu intra-glacial curvilineations troughs (IGCT).

Zagłębienia bezodpływowe typu IGCT są powszechnym elementem rzeźby towarzyszącym krętym wałom z erozji wód subglacjalnych. Jako formy negatywne, wcześniej definiowane jako zagłębienia międzydrumlinowe, często zajęte przez jeziora, oczka wodne oraz bagna, zostały opisane przez wielu polskich autorów (m.in. Nechay 1927, Czechówna 1952, Wiśniewski 1965, Olszewski 2000c, Wysota 2007). Nie zostały jednak szczegółowo zbadane pod względem cech sedymentologicznych i właściwości fizykochemicznych osadów wypełniających te formy. Prace rekonesansowe na tym obszarze prowadzili Karasiewicz i in. (2011), którzy na podstawie cech morfometrycznych i litologicznych wydzielili wtedy 5 typów zagłębień międzydrumlinowych. Niniejsza praca stanowi kontynuację i rozwinięcie tematyki badawczej podjętej wcześniej przez autorów. Jej celem jest analiza wpływu denudacji antropogenicznej na właściwości osadów zagłębień w odniesieniu do ich typologii.

\section{Obszar badań}

Do szczegółowych badań wytypowano pole testowe o powierzchni $1 \mathrm{~km}^{2}$, które znajduje się w okolicy miejscowości Zbójenko. Wyróżniono tutaj 9 dużych krętych wałów z erozji wód subglacjalnych oraz kilka mniejszych, charakteryzujących się rozciągłością ze wschodu na zachód i łukowatym wygięciem w kierunku północnym (ryc. 2). Największe z nich osiągają ponad $2 \mathrm{~km}$ długości, a ich szerokość jest zmienna i mieści się w zakresie od 20 do $104 \mathrm{~m}$. Wysokość krętych wałów z erozji wód subglacjalnych waha się od 1 do $15 \mathrm{~m}$. Ich części grzbietowe mają średnio rzędne w przedziale 100-103 m n.p.m. W środkowym fragmencie pola testowego osiągają one maksymalną wysokość 105 m n.p.m. Nachylenie stoków analizowanych wałów wynosi przeciętnie $5-7^{\circ}$, a maksymalne nie przekracza $25^{\circ}$

W obrębie pola testowego wyróżniono 60 bezodpływowych form IGCT, zamkniętych zlewniami bezpośrednimi o zróżnicowanej morfometrii. Ich dna były położone na wysokościach od 93 do 98 m n.p.m. Były to głównie formy pojedyncze, oddzielone od sąsiednich wyraźnym progiem, jedynie w kilku przypadkach zinwentaryzowano formy złożone. W dnach większości IGCT występowały niewielkie, stałe lub okresowe oczka wodne. Miąższość 




Ryc. 2. Rzeźba obszaru badań - okolice Zbójenka, niedaleko Zbójna

Fig. 2. The relief of the study area - the surroundings of Zbójenko, near Zbójno

osadów dennych (stokowych i hydrogenicznych) wahała się $\mathrm{w}$ granicach od 0,3 do $6,2 \mathrm{~m}$.

Noryśkiewicz i in. (2010) na podstawie danych archeologicznych wykazali, że w obrębie kilku kilometrów od stanowiska znane są ślady obecności ludności kultur neolitu (kultura amfor kulistych), brązu oraz żelaza (kultura łużycka, wielbarska, przeworska). Stwierdzono, że najliczniejsze są stanowiska osadnicze z okresu średniowiecza. Dane palinologiczne z tego obszaru wskazują na osiem faz wzmożonej aktywności człowieka. Najsilniej zmiany w szacie roślinnej zachodziły od VIII w. n.e. (Noryśkiewicz i in. 2010, Karasiewicz i in. 2011), zatem można przypuszczać, że przekształcenia rzeźby analizowanego obszaru powodowane intensyfikacją działalności człowieka następują już od średniowiecza. Ostatnie 100-200 lat charakteryzuje się natomiast nasileniem przekształceń rzeźby krajobrazu rolniczego w wyniku stosowania ciężkiego sprzętu agrotechnicznego.

\section{Metody badań}

Badania terenowe przeprowadzono $\mathrm{w}$ sezonie letnim 2011 r. W dnach IGCT opracowano 12 wkopów i kilkadziesiąt sondowań ręcznych (ryc. 3). Wkop lub sondowanie sięgały do poziomu gliny morenowej, którą przyjęto jako podłoże osadów wypełniających analizowane zagłębienia. Na tej podstawie wytypowano 4 profile badawcze, reprezentujące różne typy wypełnień w obrębie IGCT (Karasiewicz i in. 2011). W ich lokalizacji zastosowano zasadę centralnego i najniżej położonego miejsca w dnie zagłębienia. W celach porównawczych badaniami objęto także grzbiet krętego wału z erozji wód subglacjalnych (jeden profil). Do szczegółowych badań laboratoryjnych pobrano łącznie 43 próbki osadów oraz 14 próbek wód z oczek śródpolnych.

Oznaczenia parametrów fizycznych i cech chemicznych osadów obejmowały:

- analizę uziarnienia metodą areometryczną Bouyoucosa w modyfikacji Casagrande'a i Prószyńskiego oraz metodą sitową,

- określenie zawartości węgla organicznego $\left(\mathrm{C}_{\text {org }}\right)$ i azotu ogółem $\left(\mathrm{N}_{\mathrm{t}}\right) \mathrm{z}$ wykorzystaniem analizatora elementarnego CHN typu Vario MACRO firmy Elementar Analysensysteme $\mathrm{GmbH}$,

- oznaczenia $\mathrm{pH}$ w $\mathrm{H}_{2} \mathrm{O}$ przy stosunku osad:woda 1:2,5 dla próbek mineralnych, 1:5 dla mineralno-organicznych oraz 1:10 dla organicznych - metodą potencjometryczną,

- określenie zawartości kationów zasadowych (w ekstrakcie 1:5): $\mathrm{Ca}^{2+}$ i $\mathrm{Mg}^{2+}$ - metodą spektrometrii absorpcji atomowej (AAS), $\mathrm{Na}^{+}$i K $\mathrm{K}^{+}$- metodą spektrometrii emisyjnej (ES),

- określenie zawartości $\mathrm{Pb}, \mathrm{Zn}$ i Cu ekstrahowanych za pomocą 0,5 -molowego roztworu $\mathrm{HCl}$ (ekstrakt 1:5) metodą AAS.

W próbkach wód wykonano podstawowe pomiary parametrów fizykochemicznych, tj. odczynu $(\mathrm{pH})$ - metodą potencjometryczną oraz przewodności elektrycznej (EC) - metodą konduktometryczną. Ponadto dla próbek wody oznaczono ich skład jonowy w następujący sposób:

- $\mathrm{Cl}^{-}$metodą miareczkowania argentometrycznego,

- $\mathrm{HCO}_{3}^{-}$metodą miareczkowania acydymetrycznego,

- $\mathrm{SO}_{4}^{2-}$ metodą turbidymetryczną, 


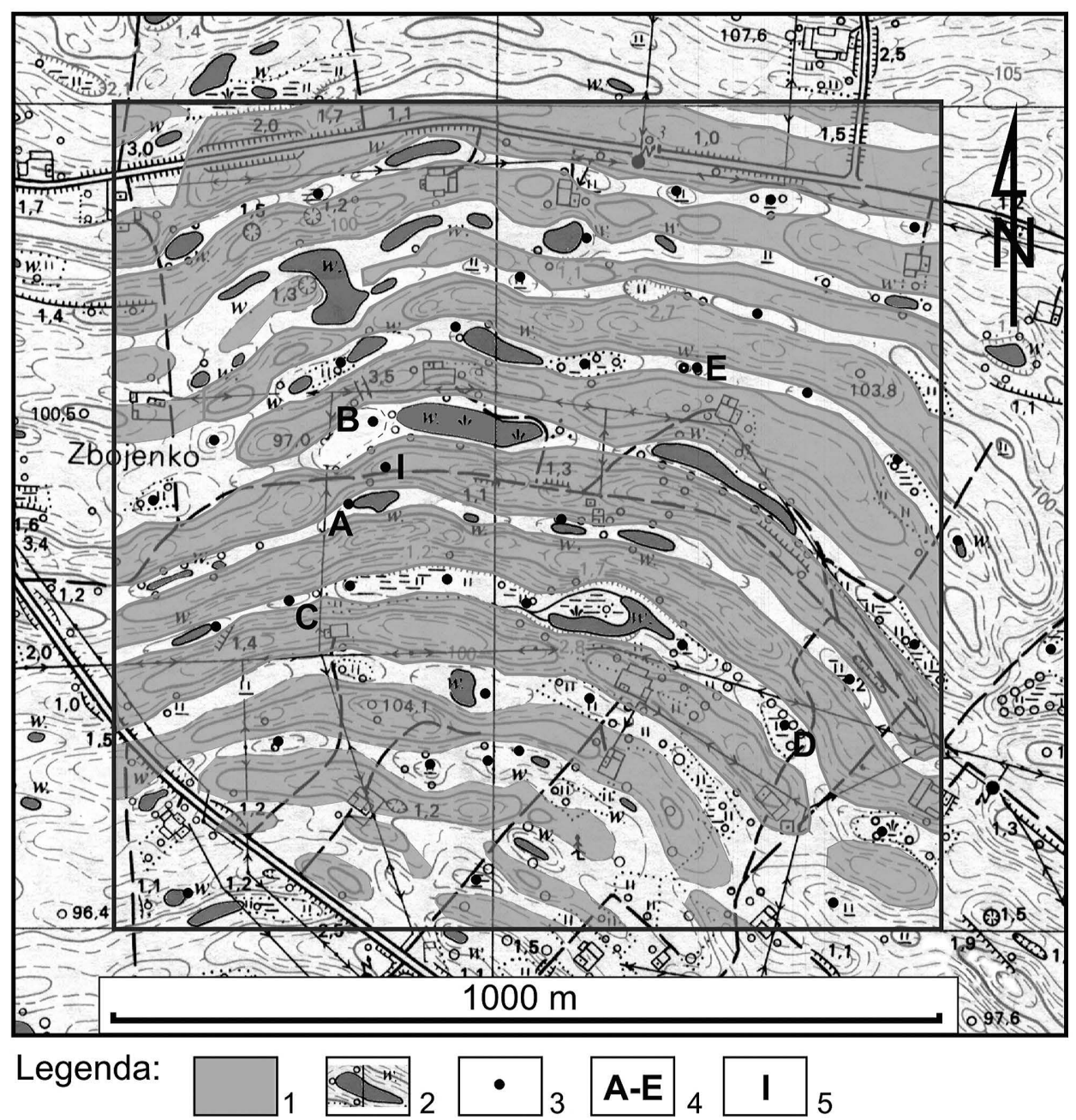

Ryc. 3. Mapa dokumentacyjna pola testowego

1 - kręte wały z erozji wód subglacjalnych, 2 - wody, 3 - stanowiska badawcze, 4 - typy zagłębień, 5 - stanowisko porównawcze na grzbiecie krętego wału z erozji wód subglacjalnych

Fig. 3. Map of the study area

1 - glacial curvilineations, 2 - waters, 3 - study sites, 4 - types of the intra-glacial curvilineation, 5 -reference site on the ridge of a glacial curvilineation

- $\mathrm{K}^{+}, \mathrm{Na}^{+}$metodą ES,

- $\mathrm{Ca}^{2+}$ i $\mathrm{Mg}^{2+}$ metodą AAS.

Uzyskane wyniki zostały opracowane statystycznie. Obliczono podstawowe parametry pomiarów, takie jak średnia $\left(\mathrm{x}_{\mathrm{sr}}\right)$, minimum $\left(\mathrm{x}_{\min }\right)$, maksimum $\left(\mathrm{x}_{\max }\right)$ oraz odchylenie standardowe $(\sigma)$.

\section{Charakterystyka typów zagłębień i ich wypelnień}

Siedliska podmokłe należą do obszarów najbardziej podatnych na degradację. Jak podają Koprowski i Łachacz (2012), do ich największych zagrożeń można zaliczyć m.in. melioracje, intensywne rolnictwo i nieracjonalną gospodarkę ściekową (eutrofizacja wód), niewłaściwą zabudowę obszarów wiejskich, a także wylesianie i fragmentacje siedlisk. Według tych autorów intensywny rozwój rolnictwa i osuszanie terenu w okolicach Zbójna od XIX w. przyczyniły się do zmniejszenia powierzchni mokradeł o $16 \%$, liczby mokradeł o $41 \%$, a długości ich granic o $49 \%$.

Cechą charakterystyczną badanych zagłębień (form typu IGCT) jest występowanie w ich dnach serii osadów paludycznych (torfów) oraz limnicznych (mułków, iłów, gytii). Ich sumaryczna miąższość jest zróżnicowana i wynosi od kilkunastu centymetrów do kilku metrów. Podłoże osadów dennych stanowi glina morenowa o szarej barwie. Niektóre z analizowanych form IGCT są częściowo wypełnione materiałem o charakterze tzw. diamiktonu rolnego. Według Sinkiewicza (1998) są to osady deluwialne przemieszczane $\mathrm{w}$ dół stoku w wyniku procesów antropogenicznych (np. denudacja agrotechniczna, inaczej tzw. erozja uprawowa), nakładających się na naturalne procesy stokowe. Stochlak (1996) tego typu osady klasyfikuje jako deluwia rolne. Znaczna miąższość deluwiów oraz występowanie bezpośrednio pod nimi dobrze wykształconych gleb kopalnych świadczą o tym, że tempo przekształceń stoków w krajobrazie rolniczym nasiliło się w ostatnich 100-200 latach (Frelinghaus, Vahrson 1998, Sinkiewicz 1998, Küster i in. 2011). 
W obrębie pola testowego położonego w okolicy Zbójna wydzielono 5 typów wypełnień w formach IGCT. Pierwszy z nich obejmuje zagłębienia, których dna stale są zalane przez wodę. Pozostałe cztery typy IGCT były wyróżnione na podstawie ich parametrów morfometrycznych oraz cech strukturalnych i teksturalnych osadów dennych (ryc. 4) (por. Karasiewicz i in. 2011). W ten sposób wydzielone typy form IGCT w rejonie Zbójna to:

- typ A - niewielkie formy (nie przekraczające $150 \mathrm{~m}$ długości, 2 m głębokości) z oczkami wodnymi o właściwościach wód uwarunkowanych rodzajem podłoża oraz sposobem użytkowania zlewni, w ich dnie występuje gytia na glinie morenowej,

- typ B - duże formy (zdecydowanie przekraczające $100 \mathrm{~m}$ długości) wypełnione torfami przejściowymi i wysokimi (o miąższości do 4-5 m), przykrywającymi gytię,

- typ C - płytkie (miąższość osadów dennych do 1,2 $\mathrm{m}$ ), małe formy wypełnione w spągu płytkowodnymi osadami mineralnymi (ił lub diamikton ilasty - deluwia), przykryte osadami organicznymi (miejscami z glebami kopalnymi), na których zalegają deluwia (diamikton rolny),

- typ D - formy o średniej wielkości, do $100 \mathrm{~m} \mathrm{dłu-}$ gości, wypełnione w spągu płytkowodnymi osadami mineralnymi (ił lub diamikton), przykrytymi torfem,

- typ E - formy małe (do $50 \mathrm{~m}$ długości, 10-20 m szerokości), zanikające w wyniku zasypywania i zaorywania przez człowieka, wypełnione deluwiami (diamiktonem rolnym).

Szczególną uwagę w analizie osadów dennych w obrębie IGCT poświęcono relacji ich cech fizykochemicznych, strukturalnych i tekstualnych w stosunku do dynamiki denudacji antropogenicznej.

Typ A obejmował małe zbiorniki (oczka) wodne o powierzchni od kilku $\mathrm{m}^{2}$ do kilku ha (ryc. 4, 5). Stanowią one bardzo powszechnie występujący element rzeźby młodoglacjalnej (Koc, Polakowski 1990, Major 2003, 2009, Kalettka, Rudat 2006). Wielu autorów (np. Cooper, Knight 1990, Kochanowska i in. 1998, Koc i in. 2001) podkreśla specyficzną i ważną funkcję, którą pełnią te formy w krajobrazie rolniczym. Tworzą one tzw. barierę biogeochemiczną powodującą ograniczenie rozprzestrzeniania się różnych zanieczyszczeń, takich jak związki biogenne, środki ochrony roślin oraz metale ciężkie. Według Podlasińskiej (2012) chemizm wód i osadów oczek wodnych (centralne punkty mikrozlewni) jest uzależniony od dostawy pierwiastków z obszaru zlewni oraz od zdolności osadów do sorbowania różnych makroi mikroelementów.

Wody badanych zbiorników charakteryzują się odczynem od słabo kwaśnego do zasadowego (pH 6,2-7,8). Zawartość substancji rozpuszczonych jest w nich dość zróżnicowana, o czym świadczy zakres przewodności elektrycznej (EC) od 140 do $845 \mu \mathrm{S} \mathrm{cm}^{-1}$ (tab. 1). Zgodnie z klasyfikacją Alekina (1956) wśród analizowanych próbek przeważają wody o średnim lub podwyższonym stopniu mineralizacji (suma jonów głównych wynosi- ła maksymalnie $773 \mathrm{mg} \mathrm{dm}^{-3}$ ). Należą one głównie do następujących typów hydrochemicznych: $\mathrm{HCO}_{3}-\mathrm{Ca}$, $\mathrm{HCO}_{3}$-Ca-Mg i $\mathrm{HCO}_{3}-\mathrm{Cl}-\mathrm{Ca}$ (Macioszczyk 1987). Najniższe stężenia wszystkich analizowanych jonów, a także najniższe wartości EC i pH zanotowano w przypadku trzech próbek pobranych z oczek otoczonych przez pasy krzewów i drzew (ryc. 5). Pasy te stanowią strefę buforową ograniczająca dopływ do oczek wodnych biogenów i $\mathrm{CaCO}_{3}$, ługowanego $\mathrm{z}$ osadów budujących kręte wały z erozji wód subglacjalnych. Pozostałe próbki wód wy-

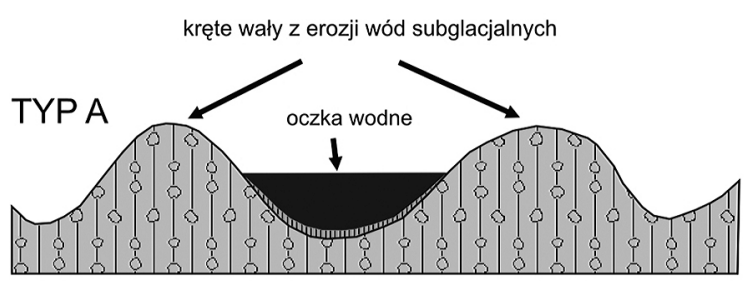

TYP B
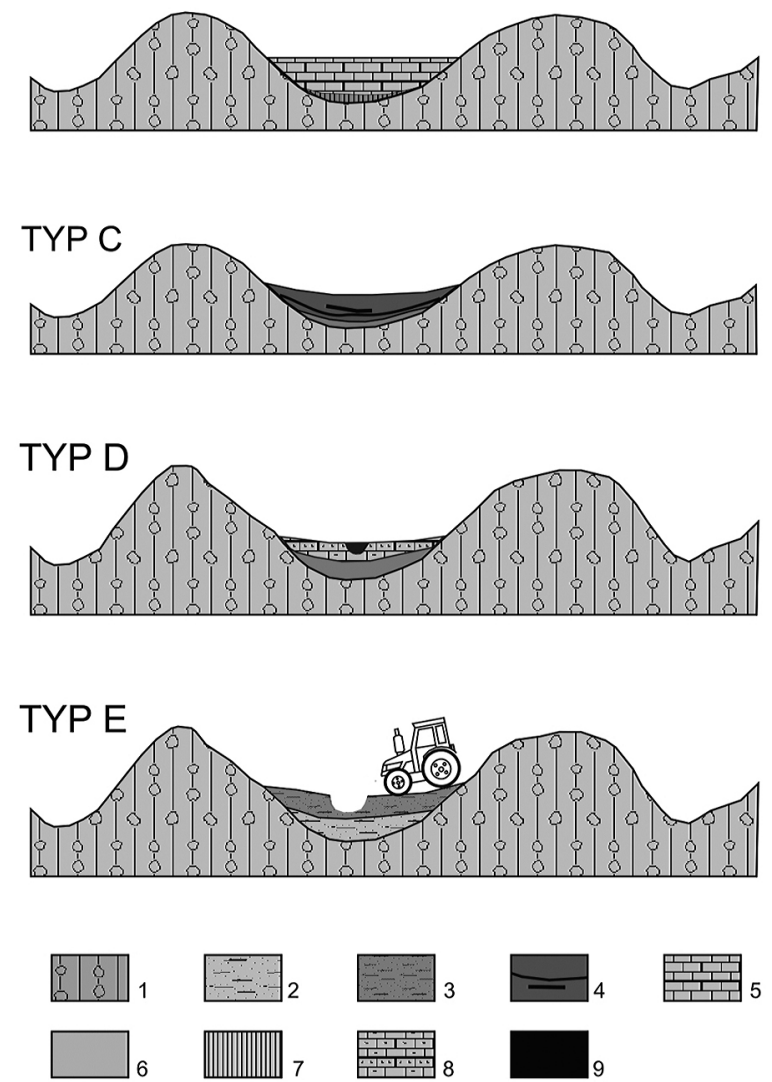

Ryc. 4. Typy zagłębień między krętymi wałami z erozji wód subglacjalnych (za Karasiewicz i in. 2011, zmienione)

1 - glina lodowcowa, 2 - naturalne osady deluwialne, 3 - diamikton rolny, 4 - osady deluwialne z glebami kopalnymi, 5 - torf (często torf torfowiska wysokiego ze Sphagnum sp.), 6 - ił, ilaste deluwia gliniaste, 7 - gytia (osady jeziorne), 8 - torf $z$ domieszką materiału mineralnego (zamulony) i piaski próchniczne, 9 - woda (małe jeziora, oczka wodne)

Fig. 4. Types of glacial curvilineations (after Karasiewicz et al. 2011, modified)

1 - glacial till, 2 - natural slope deposits, 3 - agricultural diamicton, 4 - diluvium with a buried soil horizon, 5 - peat (mainly Sphagnum sp.), 6 - clay, clayey loam, 7 - gyttja, 8 - peat with admixture of mineral material, 9 - water (small lakes or ponds) 

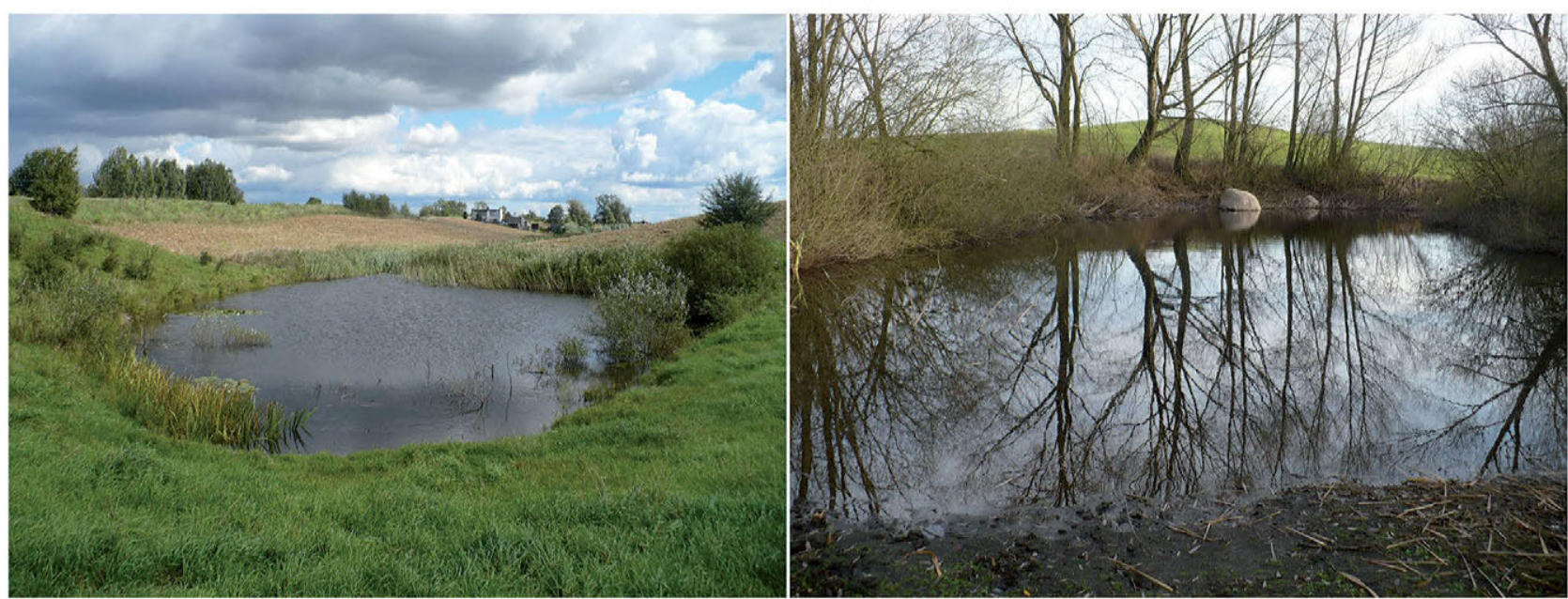

Ryc. 5. Przykłady zagłębień wypełnionych wodą - typ A

Fig. 5. Examples of A depressions filled with water - type A

różnia podwyższona zawartość potasu (do $\left.92,1 \mathrm{mg} \mathrm{dm}^{-3}\right)$, chlorków (do 80,6 $\mathrm{mg} \mathrm{dm}^{-3}$ ) oraz fosforanów (do $0,65 \mathrm{mg}$ $\mathrm{dm}^{-3}$ ), co niewątpliwie jest związane z rolniczym użytkowaniem zlewni (Major 2003, Brysiewicz i in. 2013).

Typ B stanowi dość rzadki element krajobrazu krzywych lineacji glacjalnych. W czasie badań terenowych na polu testowym tylko $\mathrm{w}$ trzech przypadkach natrafiono na osady jeziorne, o miąższości nie przekraczającej zwykle $1 \mathrm{~m}$, na których zalegają torfy wysokie lub przejściowe. Na rycinach 6,7 i 8 przedstawiono charakterystykę stropowej części osadów jednego $\mathrm{z}$ takich zagłębień (do głębokości $1,3 \mathrm{~m}$ ). Są to osady silnie kwaśne (pH 4,3-5,0) i generalnie ubogie w $\mathrm{Ca}, \mathrm{Mg}, \mathrm{K}, \mathrm{Na}, \mathrm{Pb}, \mathrm{Zn}$ i Cu. Jedynie $\mathrm{w}$ 10-centymetrowej warstwie powierzchniowej stwierdzono niewielkie nagromadzenie tych pierwiastków, a szczególnie cynku (ok. $50 \mathrm{mg} \mathrm{kg}{ }^{-1}$ ) (ryc. 7). Ich koncentracja może mieć związek z dopływem materii mineralnej (zamuleniem torfu) spowodowanym procesami denudacji zlewni.

Całkowita miąższość osadów torfowych (Sphagnum sp.) przykrywających gytię wynosi w formach typu B prawie $5 \mathrm{~m}$. Badania Karasiewicza i in. (2011) wykazały, że początek sedymentacji jeziornej nastąpił w nich prawdopodobnie już u schyłku najstarszego dryasu, zaś torfowisko zaczęło się formować w okresie preborealnym.

Do typu C zaliczono zagłębienia płytkie (do 1,2 m osadów) i o małej powierzchni dna (do kilku arów), dość powszechnie spotykane na badanym obszarze. Otaczają- ce je kręte wały z erozji wód subglacjalnych położone są blisko siebie, podobnie jak i progi oddzielające poszczególne formy IGCT. Zagłębienia te w spągu wypełnione są płytkowodnymi osadami o uziarnieniu typowym dla diamiktonów ilastych i iłów, na których mogą występować organiczne gleby kopalne (zawartość $\mathrm{C}_{\text {org }}$ do $20 \%$ ). Strop wypełnień typu $\mathrm{C}$ form IGCT stanowią natomiast osady stokowe (deluwialne), tj. mułki, mułki piaszczyste i piaski drobnoziarniste o zróżnicowanej zawartości materii organicznej. W osadach tych $\mathrm{z}$ reguły nie jest widoczne smugowanie (warstwowanie), co może być efektem procesów spłukiwania rozproszonego (Smolska 2005), wielokrotnej redepozycji materiału w obrębie stoku oraz działalności organizmów glebowych (Śnieżko 1995). Najczęstszą przyczyną smugowania (warstwowania) jest jednak rolnicza uprawa gruntów (głównie orka), która powoduje homogenizację osadów (Sinkiewicz 1998, Twardy 2003, Smolska 2005, Szpikowski 2012, Świtoniak 2014). Największą zawartością frakcji piaszczystej charakteryzuje się warstwa powierzchniowa, gdzie udział frakcji o średnicy powyżej $0,1 \mathrm{~mm}$ znacznie przekracza $40 \%$ (ryc. 9). Wraz z głębokością wzrasta udział frakcji o średnicy poniżej $0,1 \mathrm{~mm}$, osiągając najwyższe wartości w środkowej części profilu (>90\%) oraz w spągu (>75\%).

Osady wypełniające typ C form IGCT są kwaśne ( $\mathrm{pH}$ $5,2-5,7)$ (ryc. 9). Najbardziej zasobne w $\mathrm{Ca}, \mathrm{Mg}$, $\mathrm{Na}$ i K są osady deluwialne, co może świadczyć o intensywnym ługowaniu chemicznym zlewni (ryc. 7). Najwyższe za-

Tabela 1. Charakterystyka statystyczna parametrów właściwości wód powierzchniowych oczek śródpolnych w rejonie Zbójenka $(19.05 .2011, \mathrm{n}=14)$

Table 1. The statistical characteristics of the parameters of surface water condition in the vicinity of Zbójenko (19.05.2011, $\mathrm{n}=14)$

\begin{tabular}{lccrrrrrrrr}
\hline \multirow{2}{*}{ Parametr } & $\mathrm{pH}$ & $\begin{array}{c}\mathrm{EC} \\
{\left[\mu \mathrm{Scm}^{-1}\right]}\end{array}$ & $\mathrm{HCO}_{3}^{-}$ & $\mathrm{SO}_{4}^{2-}$ & $\mathrm{Cl}-$ & $\mathrm{PO}_{4}^{3-}$ & $\mathrm{Na}^{+}$ & $\mathrm{K}^{+}$ & $\mathrm{Ca}^{2+}$ & $\mathrm{Mg}^{2+}$ \\
\hline $\mathrm{x}_{\text {br }}$ & 7,1 & 415 & 160,0 & 14,20 & 28,10 & 0,43 & 15,7 & 20,30 & 49,8 & 16,30 \\
\hline $\mathrm{x}_{\min }$ & 6,2 & 140 & 30,5 & 0,85 & 8,24 & 0,20 & 5,3 & 8,29 & 10,1 & 3,95 \\
\hline $\mathrm{x}_{\max }$ & 7,8 & 845 & 297 & 82,70 & 80,60 & 0,65 & 56,6 & 92,10 & 88,2 & 75,10 \\
$\sigma$ & 0,6 & 209 & 90,2 & 25,10 & 20,70 & 0,16 & 16,3 & 21,50 & 23,3 & 18,00 \\
\hline
\end{tabular}

$\mathrm{x}_{\mathrm{sr}}-$ wartość średnia, $\mathrm{x}_{\min }-$ wartość minimalna, $\mathrm{x}_{\max }-$ wartość maksymalna, $\sigma$ - odchylenie standardowe

$\mathrm{x}_{\mathrm{sr}}-$ mean, $\mathrm{x}_{\min }-$ minimum value, $\mathrm{x}_{\max }-$ maximum value, $\sigma-$ standard deviation 


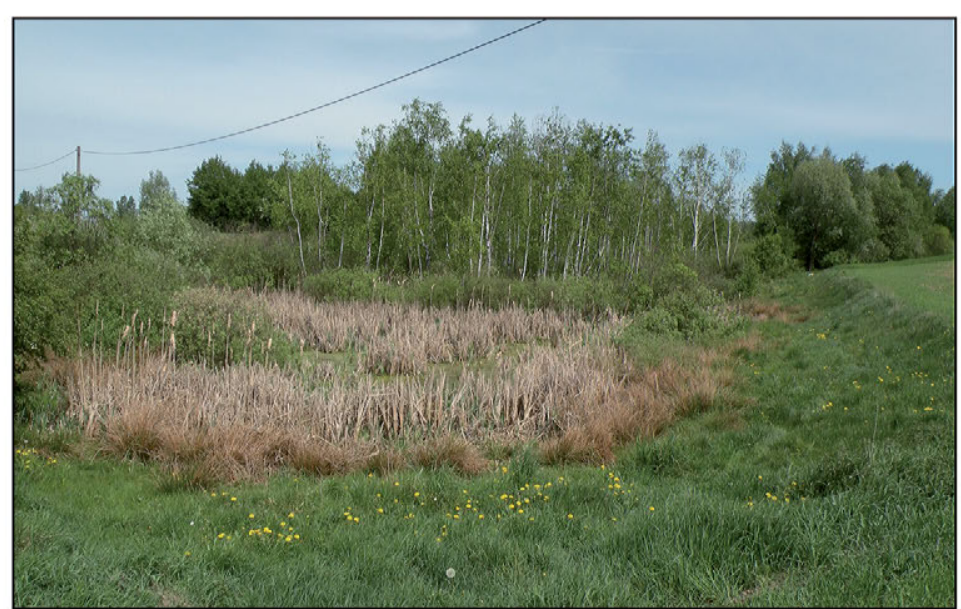

Corg

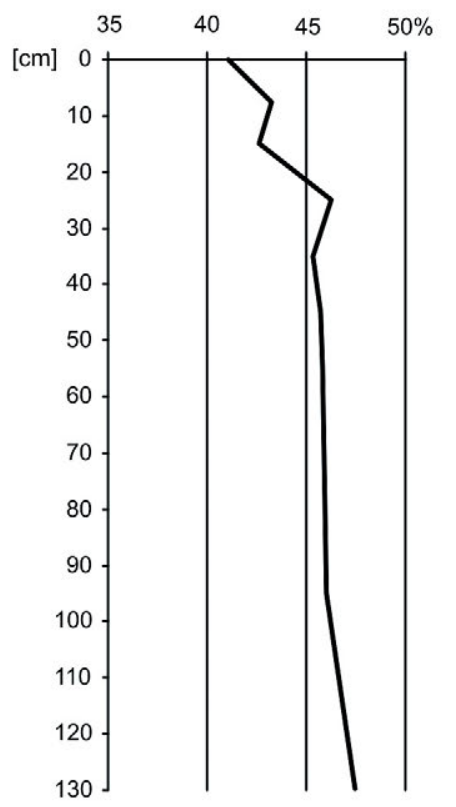

$\mathrm{pH}\left(\mathrm{H}_{2} \mathrm{O}\right)$

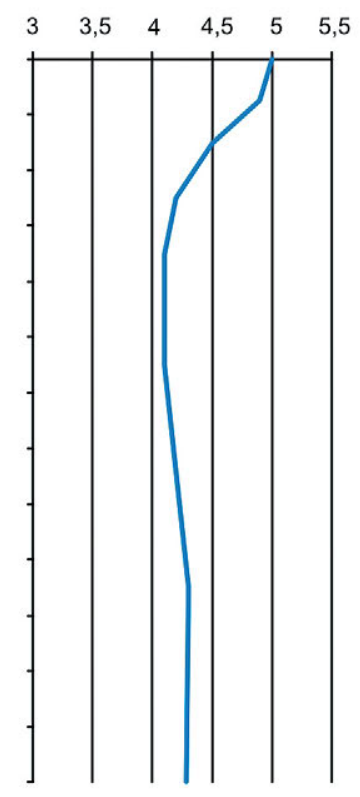

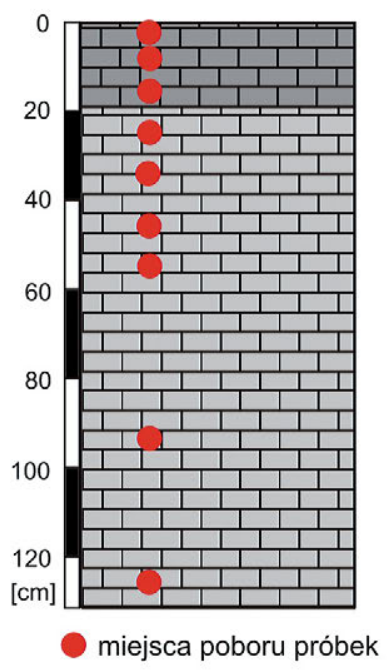

torf torfowiska

wysokiego,

zamulony, $\mathrm{H} 1$

torf torfowiska wysokiego, $\mathrm{H} 2$

Ryc. 6. Profil osadów reprezentujący zagłębienie typu B (lokalizacja stanowiska na ryc. 3)

Fig. 6. Example of sediment profiles representing depressions of type B (site location in Fig. 3)

wartości metali ciężkich $(\mathrm{Pb}-48, \mathrm{Zn}-44 \mathrm{i} \mathrm{Cu}-15 \mathrm{mg}$ $\mathrm{kg}^{-1}$ ) stwierdzono w glebie kopalnej (ryc. 8, 9). Pierwiastki te łatwo migrują w środowisku kwaśnym i są silnie sorbowane przez materię organiczną.

Typ D form IGCT występuje najrzadziej na obszarze testowym. Zlokalizowano tylko 3 stanowiska reprezentujące formy tego typu. Znajdują się w nich torfowiska o małej powierzchni (do kilku arów, długości do $100 \mathrm{~m}$ i szerokości do $50 \mathrm{~m}$ ), w których w niewielkiej części dna stagnowała woda. Dolna część profilu wypełnienia form typu D jest podobna pod względem rozkładów uziarnienia do osadów wypełniających formy typu C (ryc. 10). Występują tam również iły i diamiktony ilaste, akumulowane w warunkach płytkowodnych. Zalegające na nich laminowane osady organiczne (głównie torfowe i torfiaste; zawartość $\mathrm{C}_{\text {org }} 8-19 \%$ ) charakteryzują się znacznie większą miąższością (do $70 \mathrm{~cm}$ ) niż w przy- padku form typu C i nie są przykryte osadami deluwialnymi (ryc. 11). W formach typu D do głębokości około $30 \mathrm{~cm}$ od powierzchni zanotowano wzbogacenie torfów w materię mineralną (torfy zamulone) (ryc. 11). Istnienie tak specyficznej sekwencji osadów (brak deluwiów na powierzchni torfów) było zapewne związane $\mathrm{z}$ długotrwałym funkcjonowaniem pasa drzew i krzewów wokół zagłębienia, znacznie ograniczającego dopływ materii mineralnej spowodowanej denudacją mechaniczną (analogicznie jak w przypadku typu A). Wydaje się natomiast, że właściwości tych kwaśnych osadów organicznych w formach typu D, mających dużą zdolność zatrzymywania różnych pierwiastków, mogą odzwierciedlać skutki chemicznego ługowania zlewni (Karasiewicz $i$ in. 2014). W porównaniu z osadami innych typów zagłębień zanotowano bowiem najwyższe zawartości wapnia $\left(>600 \mathrm{mg} \mathrm{kg}^{-1}\right)$, magnezu $\left(>100 \mathrm{mg} \mathrm{kg}^{-1}\right)$, pota- 
su $\left(>140 \mathrm{mg} \mathrm{kg}^{-1}\right)$, sodu $\left(>70 \mathrm{mg} \mathrm{kg}^{-1}\right)$ oraz cynku $(>55$ $\mathrm{mg} \mathrm{kg}^{-1}$ ) (ryc. 7, 8).

Typ E form IGCT to bardzo powszechny element krajobrazu w obrębie pola testowego, związany jest genetycznie z jego silnym przekształceniem przez działania agrotechniczne, które spowodowały zmniejszenie deniwelacji w większym stopniu niż w przypadku poprzednich typów obniżeń. Na grzbietach i zboczach wałów otaczających tego typu zagłębienia widoczne są efekty silnej erozji uprawowej gleb płowych (Karasiewicz i in. 2011).
W związku z tym w dolnej części stoków, na kontakcie z częścią denną zagłębień, bardzo często mogą się tworzyć terasy z naorywania (ryc. 11, 12).

Cały profil wypełnień form IGCT typu E stanowią najczęściej kwaśne osady mineralne (diamikton rolny) $\mathrm{z}$ dominacją mułków i piasków mułkowatych, relatywnie mało zasobnych w materię organiczną (zawartość $\mathrm{C}_{\text {org }}<2 \%$ ). Osady spągowe charakteryzują się niewielką przewagą frakcji poniżej $0,1 \mathrm{~mm}$. Fakt ten można wiązać $\mathrm{z}$ domieszką osadów morenowych, ponieważ w środko-
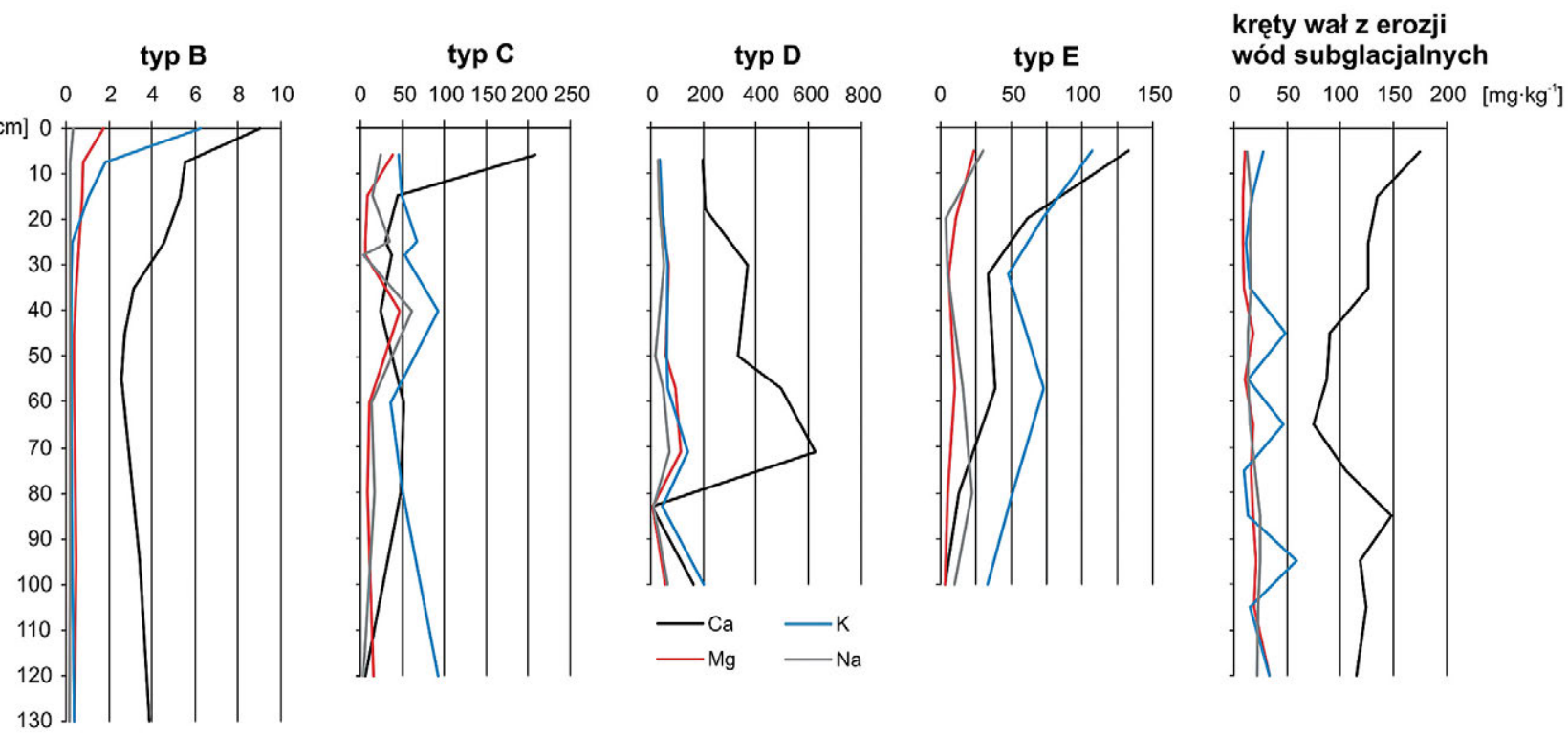

Ryc. 7. Zawartość kationów zasadowych w osadach reprezentujących różne typy form IGCT oraz w części grzbietowej krętego wału z erozji wód subglacjalnych

Fig. 7. The content of base cations within the bottom sediments of different types of IGCT forms and within the sediments of glacial curvilineations ridge

typ B

$\begin{array}{llllll}0 & 10 & 20 & 30 & 40 & 50\end{array}$

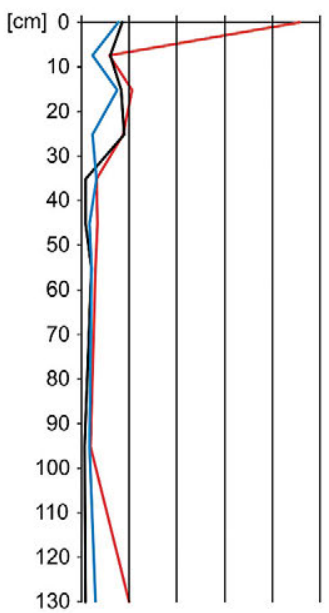

typ C

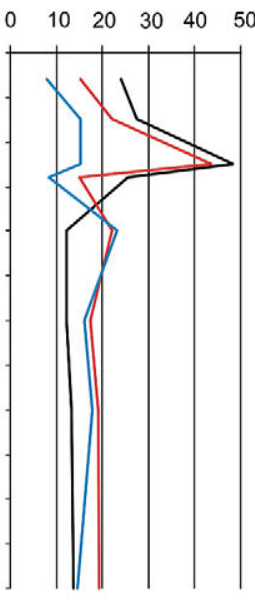

typ D

$0 \quad 102030405060$

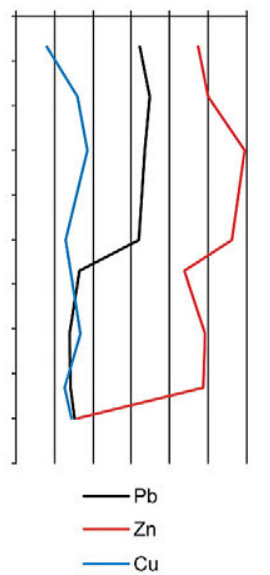

typ $E$
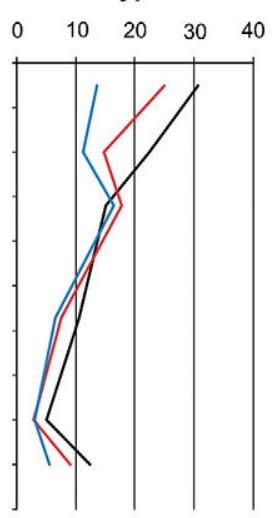

kręty wał z erozji wód subglacjalnych $\begin{array}{llllll}0 & 2 & 4 & 6 & 8 & {\left[\mathrm{mg} \mathrm{kg}^{-1}\right]}\end{array}$

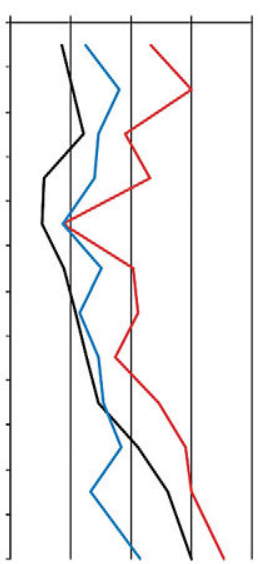

Ryc. 8. Zawartość wybranych metali ciężkich w osadach dennych reprezentujących różne typy form IGCT oraz osadów części grzbietowej krętego wału z erozji wód subglacjalnych

Fig. 8. The content of selected heavy metals within the bottom sediments representing different types of IGCT and the within sediments of glacial curvilineations ridge 
wej części profilu frakcja drobnopiaszczysta, mułkowa i ilasta stanowi ponad 90\% składu granulometrycznego, podczas gdy w stropie udział tych osadów zmniejsza się do 75-77\% (ryc. 11). Maksymalne zawartości kationów zasadowych i metali ciężkich zanotowano w warstwie powierzchniowej (0-15 cm) (ryc. 7, 8).

\section{Osady wypełniające zagłębienia w relacji do osadów krętych wałów $z$ erozji wód subglacjalnych}

Osady wypełniające formy IGCT charakteryzują się większą zawartością frakcji drobnoziarnistych ze względu na duży udział materiału ilastego w osadach limnicznych niż osady budujące powierzchnię krętych wałów z erozji wód subglacjalnych. Ponadto w obniżeniach tych stwierdzono znacznie wyższą zawartość węgla organicznego (akumulacja biogeniczna i próchnicznego materiału deluwialne-

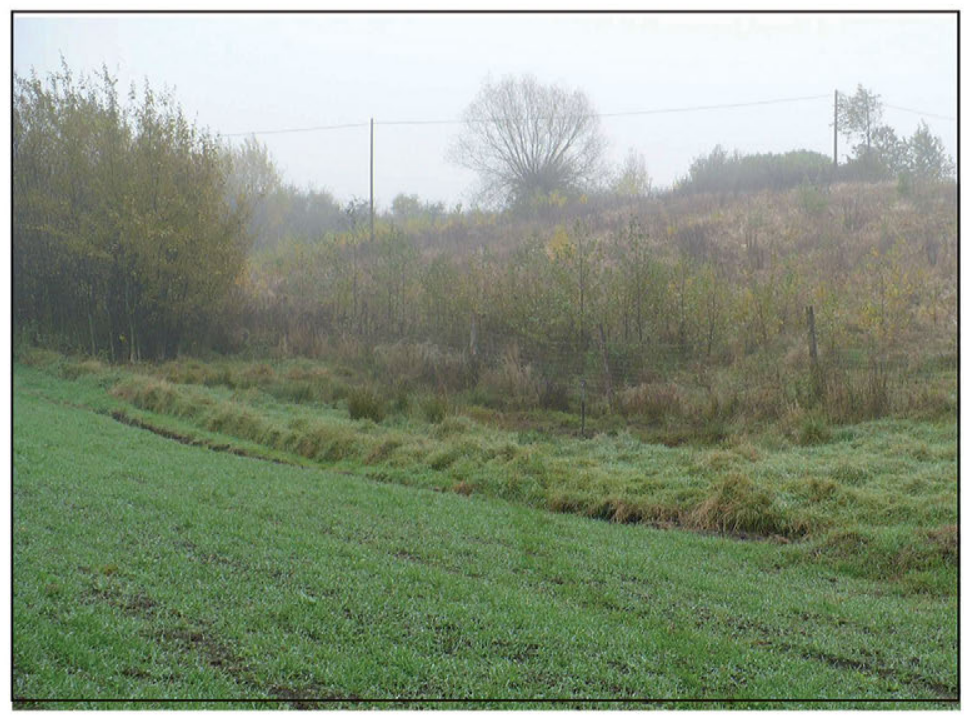

[cm]

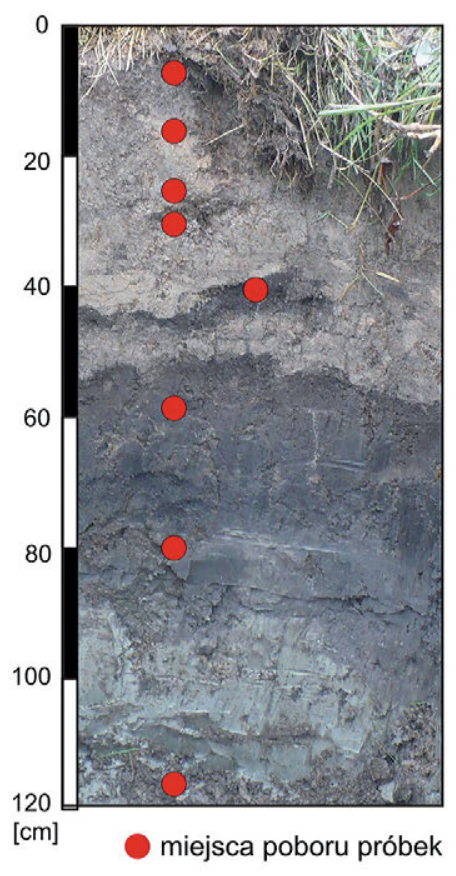

Uziarnienie

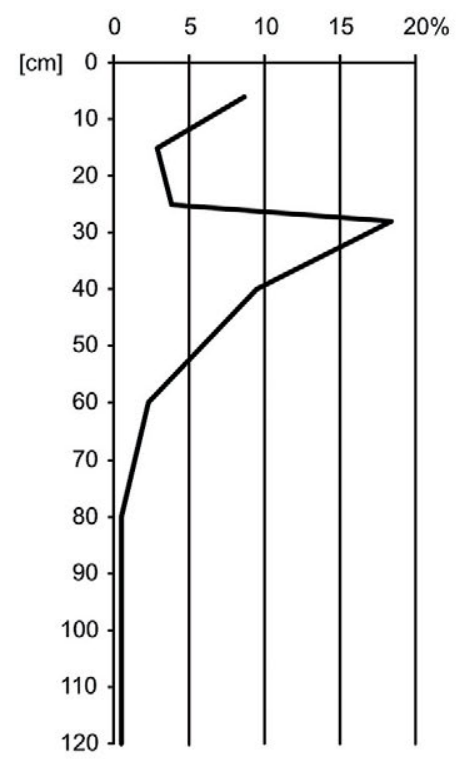

$\mathrm{pH}\left(\mathrm{H}_{2} \mathrm{O}\right)$
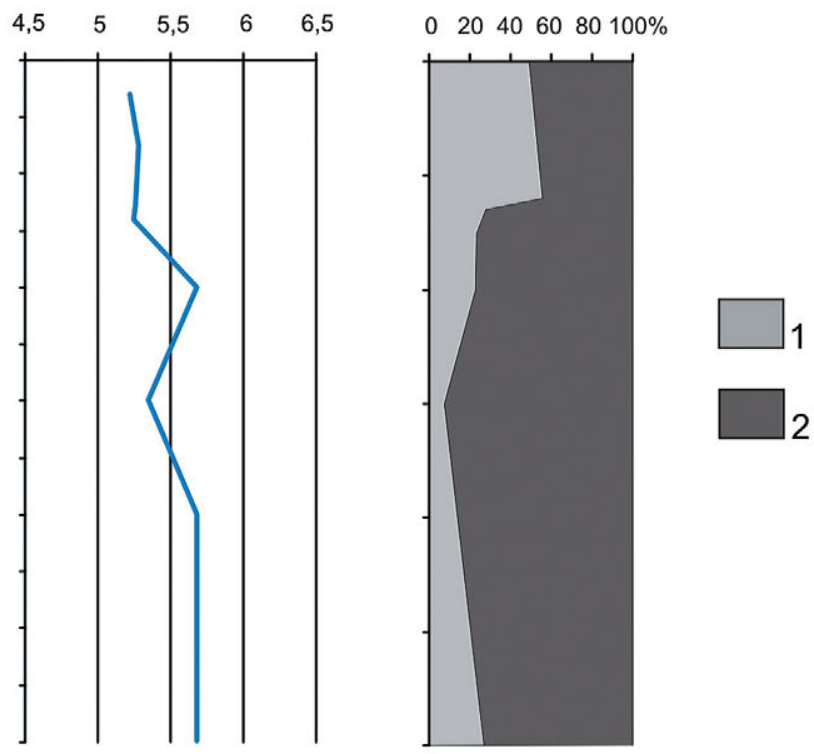

Ryc. 9. Osady denne w zagłębieniu typu C

1 - ziarna o średnicy większej od 0,1 mm, 2 - ziarna o średnicy mniejszej od 0,1 mm (lokalizacja stanowiska na ryc. 3)

Fig. 9. The bottom sediments in depression of type $C$

1 - grains with diameter up to $0,1 \mathrm{~mm}, 2$ - grains with diameter over $0,1 \mathrm{~mm}$ (site location in Fig. 3) 

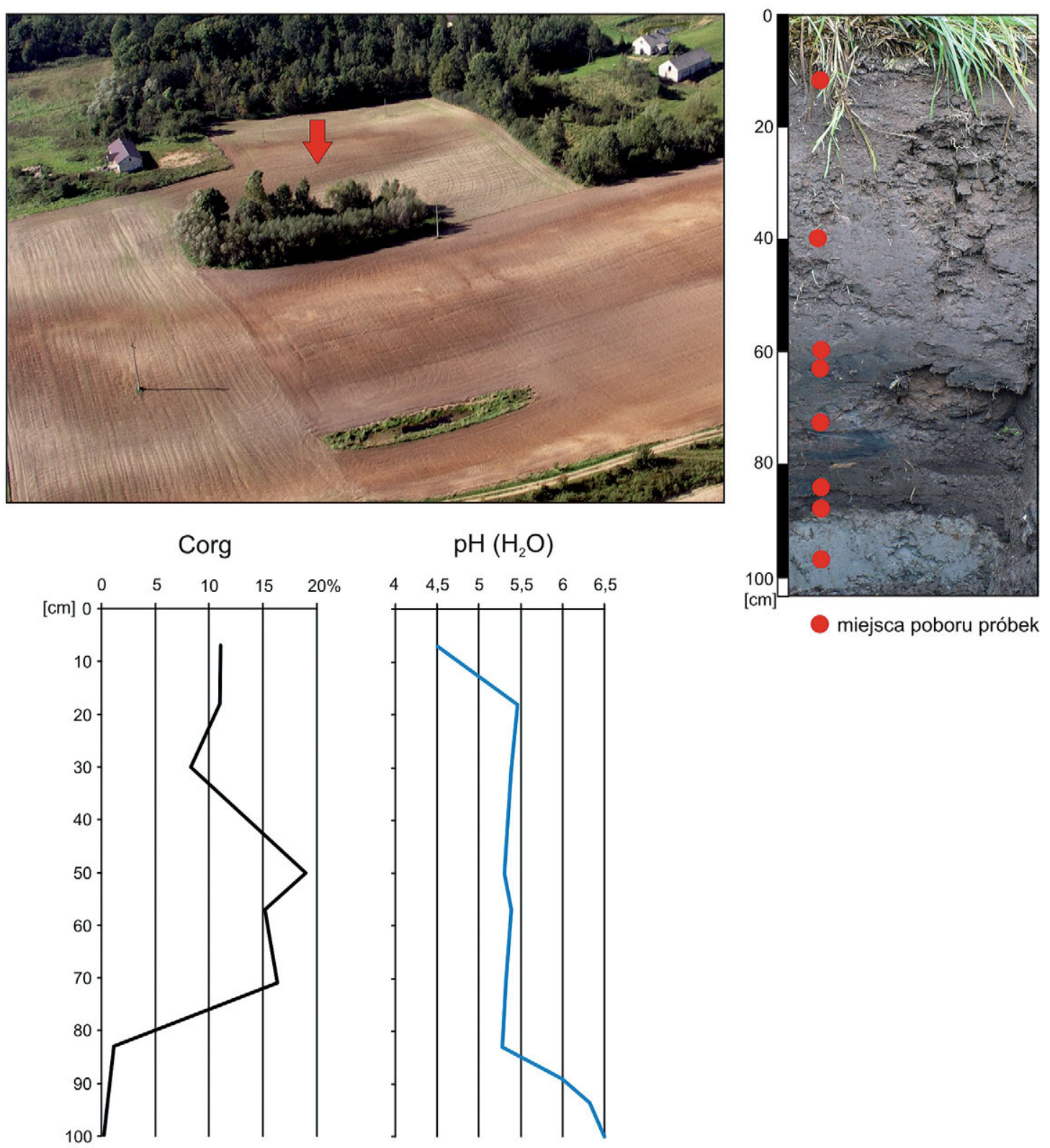

miejsca poboru próbek

Ryc. 10. Osady denne w zagłębieniu typu D (lokalizacja stanowiska na ryc. 3)

Fig. 10. The bottom sediments in depression of type D (site location in Fig. 3)

go), kationów zasadowych i metali ciężkich (ługowanie $\mathrm{z}$ obszaru zlewni bezpośrednich) niż w otaczających je wałach. Istotną cechą osadów deluwialnych przykrywających kopalne gleby torfowe i limnowe jest brak węglanów oraz niższe wartości pH (ryc. 13, tab. 2), w porównaniu z materiałem budującym powierzchniowe poziomy gleb na kulminacjach wałów krzywych lineacji glacjalnych. Różnice te wiążą się z silnymi przekształceniami denudacyjnymi, jakim uległy pokrywające je gleby. Właściwości deluwiów świadczą o bezwęglanowym, kwaśnym charakterze pierwotnych poziomów powierzchniowych gleb (z okresu przed uruchomieniem procesów stokowych), zajmujących wierzchowiny tych wałów. Można zatem przypuszczać, że były to gleby płowe $\mathrm{z}$ dobrze rozwiniętą strefą eluwialną. Kwaśne poziomy próchniczne i poziomy Et (luvic) tych gleb zostały zerodowane, a materiał je budujący uległ przemieszczeniu w dół stoków. Podobne przekształcenia gleb płowych odnotowano w zlewni Parzenicy (Szpikowski 2012), na Pojezierzu Krajeńskim, Chodzieskim i Chełmińskim (Kobierski 2013), na Równinie Wełtyńskiej (Podlasiński 2013) oraz na Pojezierzu Brodnickim (Świtoniak 2014).

Uzyskane wyniki badań geomorfologicznych i sedymentologicznych potwierdziły, że badane obiekty jako zagłębienia o dominującym zasilaniu opadowym pełnią w krajobrazie krętych wałów z erozji wód subglacjalnych, podobnie jak w innych typach krajobrazów młodoglacjalnych (np. Borówka 1992, Kalettka, Rudat 2006, Major 2009, Küster i in. 2011, Podlasińska 2012, Karasiewicz $\mathrm{i}$ in. 2014), funkcje pułapek sedymentacyjnych. Przechwytują one materiał pochodzący głównie z niszczenia otaczających je form wypukłych, szczególnie intensyw- 

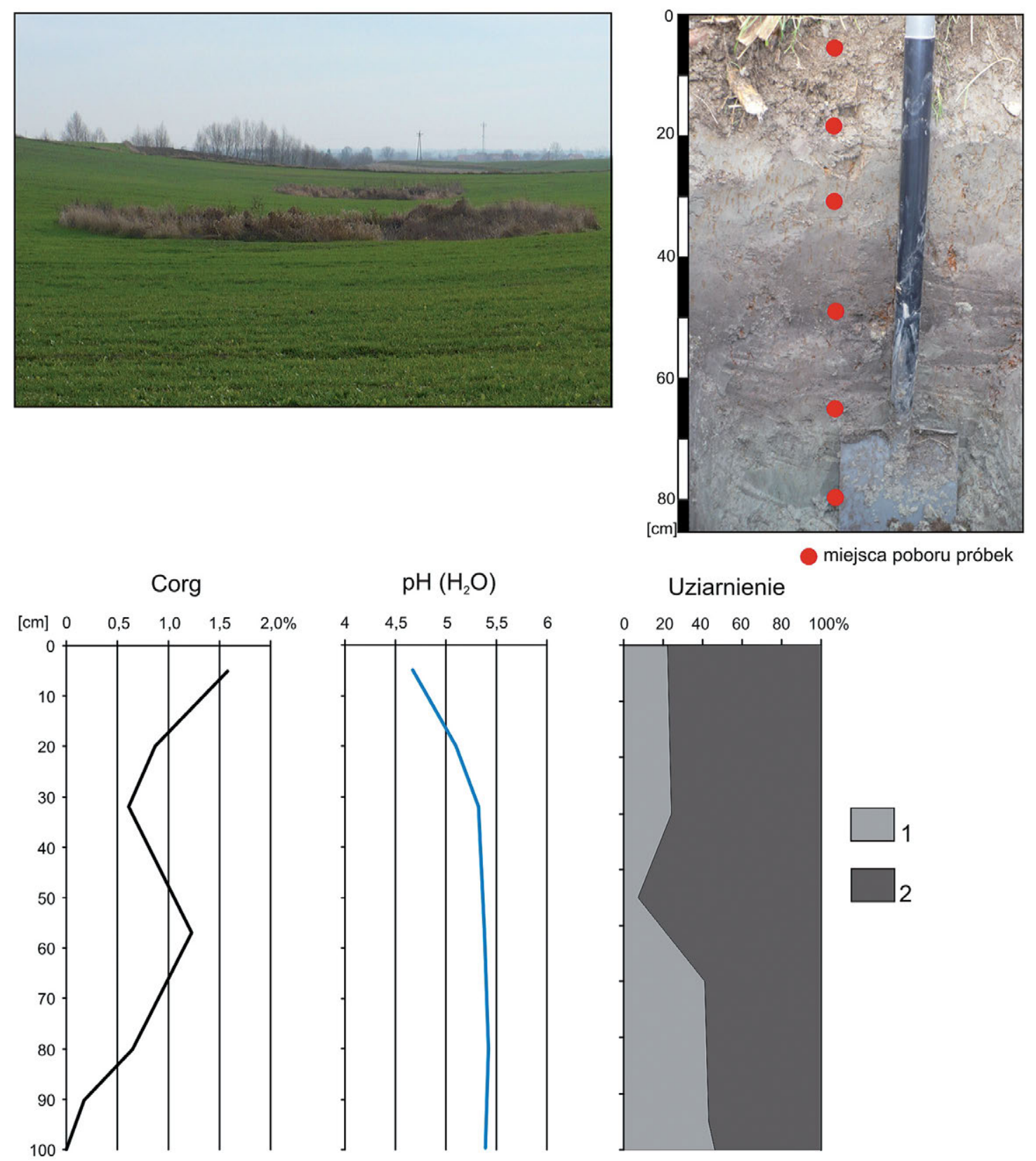

Ryc. 11. Osady denne w zagłębieniu typu $\mathrm{E}$

1 - ziarna o średnicy większej od 0,1 mm, 2 - ziarna o średnicy mniejszej od 0,1 $\mathrm{mm}$ (lokalizacja stanowiska na ryc. 3)

Fig. 11. Bottom sediments in depression of type $E$

1 - grains with diameter up to $0,1 \mathrm{~mm}, 2$ - grains with diameter over $0,1 \mathrm{~mm}$ (site location in Fig. 3)

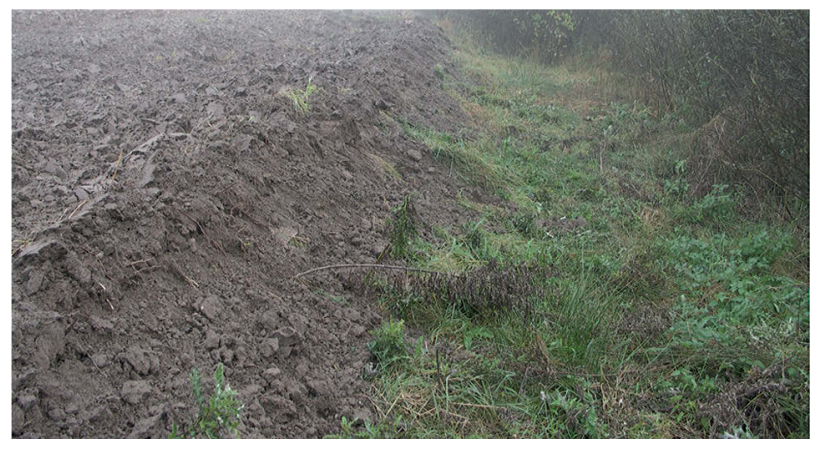

Ryc. 12. Przykład terasy rolnej na obszarze badań

Fig. 12. Example of agricultural terraces in the area of research nego na obszarach od wieloleci użytkowanych rolniczo. W wielu przypadkach wypełnienie tych zagłębień może stanowić także materiał pochodzenia autochtonicznego (iły, diamiktony ilaste, gytie, torfy).

\section{Podsumowanie}

Zagłębienia między krętymi wałami z erozji wód subglacjalnych (IGCT) są w krajobrazie rolniczym elementem stosunkowo nietrwałym. Intensywna gospodarka rolna w rejonie Zbójna przyczyniła się do obniżenia krętych 

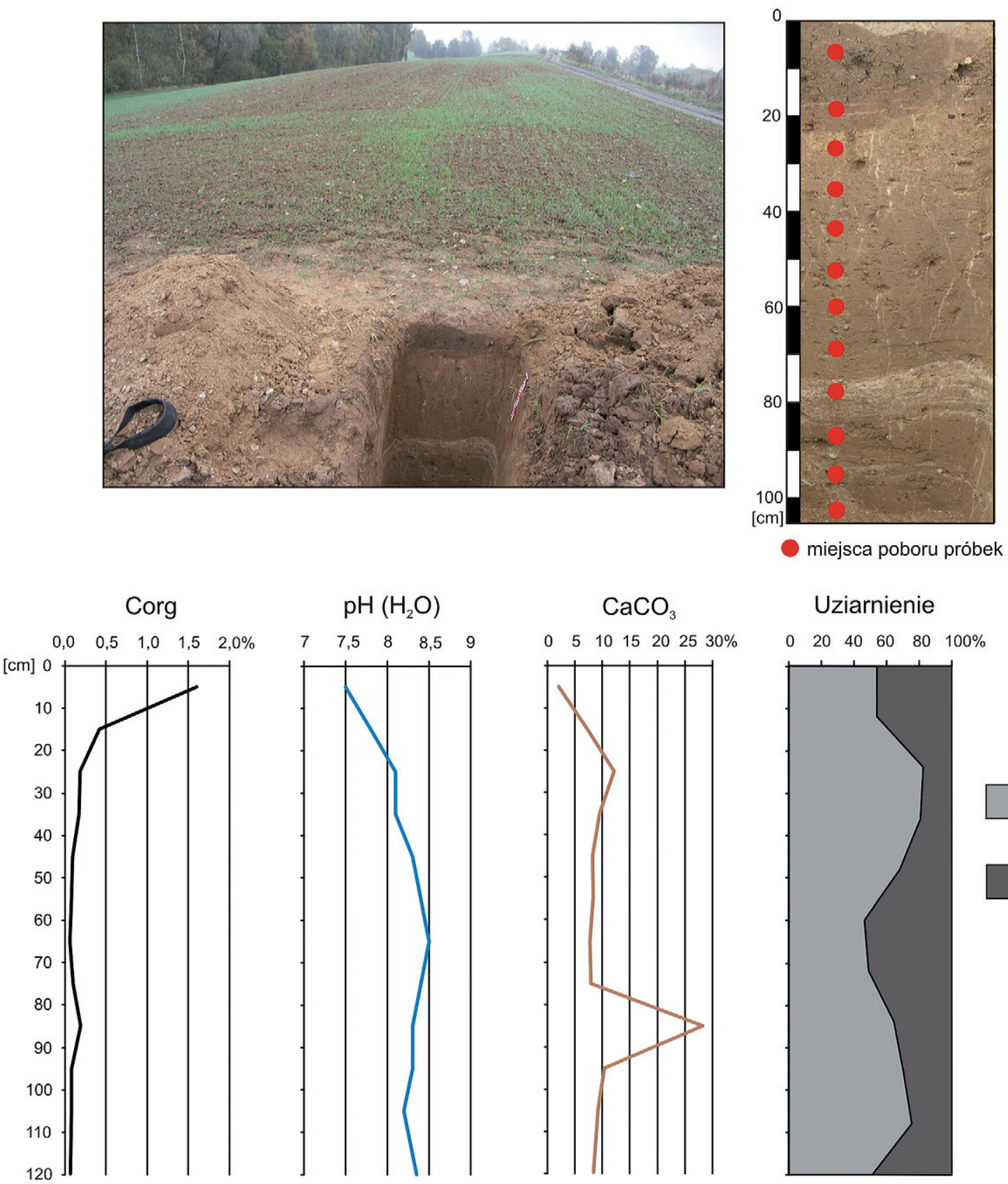

$\mathrm{CaCO}_{3}$

$\begin{array}{llllllll}0 & 5 & 10 & 15 & 20 & 25 & 30 \%\end{array}$

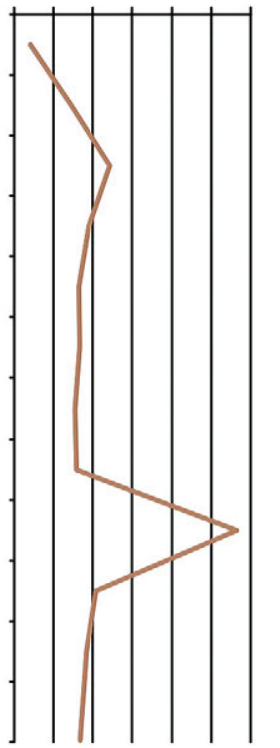

Uziarnienie

$\begin{array}{llllll}0 & 20 & 40 & 60 & 80 & 100 \%\end{array}$

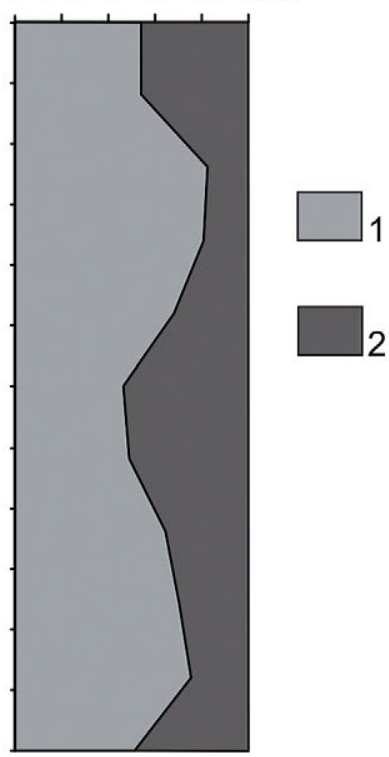

Ryc. 13. Osady grzbietu krętego wału $z$ erozji wód subglacjalnych

1 - ziarna o średnicy większej od $0,1 \mathrm{~mm}, 2$ - ziarna o średnicy mniejszej od $0,1 \mathrm{~mm}$ (lokalizacja stanowiska na ryc. 3 )

Fig. 13. Sediments of glacial curvilineation ridge

1 - grains with diameter up to $0,1 \mathrm{~mm}, 2$ - grains with diameter over $0,1 \mathrm{~mm}$ (site location in Fig. 3)

wałów z erozji wód subglacjalnych i wypełniania w szybkim tempie zagłębień diamiktonem rolnym. Procesy te prowadzą w konsekwencji do wyrównywania rzeźby.

Badane zagłębienia charakteryzuje różny etap przekształceń, od form funkcjonujących jako oczka wodne typ A (sedymentacja osadów limnicznych w oczkach wodnych, denudacja zboczy), do form zanikających - typ E, które podlegają zaorywaniu (ryc. 13). Występująca w poszczególnych typach zagłębień specyficzna sekwencja osadów jest efektem oddziaływania zarówno czynników naturalnych, jak i antropogenicznych. W niektórych profilach zanotowano obecność kopalnych poziomów organicznych (torfowych), wskazujących na intensywny rozwój roślin- ności bagiennej przy względnie niewielkim nasileniu procesów denudacyjnych. Sedentacja torfów mogła zostać całkowicie zahamowana poprzez ich przykrycie diamiktonem rolnym (typ C) lub mogła zachodzić w stopniu ograniczonym w przypadku obecności naturalnego pasa zadrzewień i zakrzewień wokół zagłębień (typ D).

W porównaniu z osadami grzbietu krętego wału z erozji wód subglacjalnych osady form IGCT charakteryzowały się wyraźnie odmiennym chemizmem. Ich kwaśny odczyn i brak węglanów należy wiązać z erodowaniem poziomów próchnicznych i eluwialnych pierwotnych gleb płowych. Wzbogacenie osadów w kationy zasadowe i metale ciężkie może niewątpliwie wskazywać na funk- 
Tabela 2. Charakterystyka statystyczna parametrów właściwości osadów wypełniających formy IGCT oraz osadów grzbietu krętego wału z erozji wód subglacjalnych w rejonie Zbójenka

Table 2. The statistical characteristics of deposits parameters of IGCT forms and the deposits of glacial curvilineation ridge in the vicinity of Zbójenko

\begin{tabular}{|c|c|c|c|c|c|c|c|c|c|}
\hline \multirow{2}{*}{\multicolumn{2}{|c|}{ Parametr }} & \multicolumn{4}{|c|}{$\begin{array}{l}\text { Zagłębienia między krętymi wałami z erozji wó } \\
\text { subglacjalnych (IGCT) } \\
(\mathrm{n}=31)\end{array}$} & \multicolumn{4}{|c|}{ Kręty wał $\mathrm{z}$ erozji wód subglacjalnych $(\mathrm{n}=12)$} \\
\hline & & $\mathrm{x}_{\mathrm{sr}}$ & $\mathrm{x}_{\min }$ & $\mathrm{x}_{\max }$ & $\sigma$ & $\mathrm{x}_{\mathrm{st}}$ & $\mathrm{x}_{\min }$ & $\mathrm{x}_{\max }$ & $\sigma$ \\
\hline $\mathrm{C}_{\text {org }}$ & {$[\%]$} & 17,3 & 0,21 & 47,2 & 18,7 & 0,26 & 0,06 & 1,60 & 0,43 \\
\hline $\mathrm{pH}$ & $\mathrm{H}_{2} \mathrm{O}$ & 5,1 & 4,1 & 6,1 & 0,6 & 8,2 & 7,5 & 8,5 & 0,3 \\
\hline $\mathrm{CaCO}_{3}$ & {$[\%]$} & 0,0 & 0,0 & 0,0 & 0,0 & 10,0 & 2,1 & 28,2 & 6,2 \\
\hline $\mathrm{Ca}$ & & 100 & 2,59 & 625 & 157 & 119 & 74,5 & 174 & 27,6 \\
\hline $\mathrm{Mg}$ & & 20,6 & 0,36 & 115 & 28,7 & 15,5 & 8,74 & 27,7 & 5,92 \\
\hline $\mathrm{K}$ & & 47,1 & 0,22 & 142 & 38,3 & 25,5 & 9,85 & 58,9 & 16,7 \\
\hline $\mathrm{Na}$ & {$\left[\mathrm{mg} \mathrm{kg}^{-1}\right]$} & 17,7 & 0,17 & 69,7 & 19,3 & 17,9 & 12,2 & 24,5 & 4,61 \\
\hline $\mathrm{Pb}$ & & 16,2 & 0,66 & 48,4 & 12,1 & 2,74 & 1,04 & 5,78 & 1,54 \\
\hline Zn & & 23,0 & 1,87 & 59,4 & 18,4 & 4,67 & 1,75 & 6,76 & 1,37 \\
\hline $\mathrm{Cu}$ & & 10,3 & 1,62 & 23,2 & 6,11 & 2,98 & 1,73 & 3,88 & 0,61 \\
\hline
\end{tabular}

$\mathrm{x}_{\mathrm{sr}}$ - wartość średnia, $\mathrm{x}_{\min }$ - wartość minimalna, $\mathrm{x}_{\max }$ - wartość maksymalna, $\sigma$ - odchylenie standardowe

$\mathrm{x}_{\mathrm{sr}}-$ mean, $\mathrm{x}_{\min }-$ minimum value, $\mathrm{x}_{\max }-$ maximum value, $\sigma-$ standard deviation

cjonowanie tych zagłębień jako pułapek sedymentacyjnych. Akumulacji tych pierwiastków sprzyjała obecność drobnoziarnistych osadów mineralnych i utworów organicznych, słaba przepuszczalność osadów podłoża oraz przeważające na tym obszarze zasilanie opadowe.

Autorzy niniejszego opracowania uważają, że stosowany termin ,kręte wały z erozji wód subglacjalnych” jest długi i opisowy, dlatego proponują dla tych form wprowadzić nowy termin geomorfologiczny ,kewes” lub „kewe$s a "$ (w liczbie mnogiej ,kewesy"), czego odpowiednikiem w języku angielskim jest ,glacial curvilinealions".

\section{Podziękowanie}

Badania były finansowane z projektu NCN nr N N306 282935 pt. „Późnovistuliańskie i holoceńskie osady basenów sedymentacyjnych jako zapis zmian paleogeograficznych na wybranych przykładach z młodoglacjalnego obszaru północno-środkowej Polski”.

\section{Literatura}

Alekin O.A., 1956. Podstawy hydrochemii. Wydawnictwo Geologiczne, Warszawa.

Borówka K.R., 1992. Przebieg i rozmiary denudacji w obrębie śródwysoczyznowych basenów sedymentacyjnych podczas późnego vistulianu i holocenu. UAM, Poznań.

Brysiewicz A., Wesołowski P., Rawicki K., 2013. Porównanie stężenia składników chemicznych w wodzie ze śródpolnego oczka wodnego oraz w wodzie gruntowej z przylegających terenów rolniczych. Woda-Środowisko-Obszary Wiejskie 13(2): 17-31.

Cooper C.M., Knight S.S., 1990. Nutrient trapping efficiency of a small sediment detention reservoir. Agricultural Water Management 18: 149-158.

Czechówna L., 1952/1953. Zagadnienie drumlinów w świetle literatury. Czasopismo Geograficzne 23/24: 50-90.

Frielinghaus M., Vahrson W.G., 1998. Soil translocation by water erosion from agricultural cropland into wet depressions (morainic kettle holes). Soil and Tillage Research 46: 23-30.
Głębicki P., Marks L., 2009. The origin of drumlins at Zbójno, Central Poland. Geologija 51, 3-4(67-68): 131-138.

Jewtuchowicz S., 1956. Struktura drumlinów w okolicy Zbójna. Acta Geograpica Lodziensia 7.

Kalettka T., Rudat C., 2006. Hydrogeomorphic types of glacially created kettle holes in North-East Germany. Limnologica 36: 54-64.

Karasiewicz M.T., Hulisz P., Noryśkiewicz A.M., Krześlak I., Świtoniak 2014. The record of hydroclimatic changes in the sediments of a kettle-hole in a young glacial landscape (north-central Poland). Quaternary International 328-329: 264-276.

Karasiewicz M.T., Noryśkiewicz A.M., Noryśkiewicz B., Hulisz P., Stachowicz-Rybka R., Bendych M., 2011. Poźnoglacjalne i holoceńskie zmiany środowiska w okolicach Zbójenka na Pojezierzu Brodnickim. W: M.T. Karasiewicz, P. Hulisz, A.M. Noryśkiewicz (red.), Człowiek i jego wpływ na środowisko przyrodnicze w przeszłości i czasach historycznych. Państwowy Instytut Geologiczny-Państwowy Instytut Badawczy, Warszawa: 95-105.

Kobierski M., 2013. Morfologia, właściwości oraz skład mineralny gleb płowych zerodowanych w wybranych obszarach morenowych województwa kujawsko-pomorskiego. Wydawnictwa Uczelniane Uniwersytetu Technologiczno-Przyrodniczego w Bydgoszczy.

Koc J., Cymes I., Skwierawski A., Szyperek U., 2001. Znaczenie ochrony małych zbiorników wodnych w krajobrazie rolniczym. Zeszyty Problemowe Postępów Nauk Rolniczych 476: 397-407.

Koc J., Polakowski B., 1990. Charakterystyka zagłębień bezodpływowych na Pojezierzu Mazurskim w aspekcie przyrodniczym, urządzeniowo-rolnym i rolniczym. W: R. Olaczek (red.), Użytki ekologiczne w krajobrazie rolniczym. Wydawnictwo SGGW-AR, Warszawa: 25-57.

Kochanowska R., Pieńkowski P., Podlasiński M., 1998. Characteristics of intrafield water holes in Western Pomerania in relation to differention of the Young-glacial landscape and human impact. Journal of Water Land Development 2: 85-101.

Kondracki J., 1998. Geografia regionalna Polski. PWN, Warszawa.

Koprowski J., Łachacz A., 2012. Przekształcenia środowiska Pojezierza Dobrzyńskiego: wykorzystanie w badaniach dawnych planów i map. Wydawnictwo Mantis, Olsztyn.

Küster M., Ruchhöft F., Lorenz S., Janke W., 2011. Geoarchaeological evidence of Holocene human impact and soil erosion on a till plain in Vorpommern (Kühlenhagen, NE-Germany). Quaternary Science Journal 60(4): 455-463, DOI:10.3285/eg.60.4.05.

Lamparski P., 2005. Wyniki badań georadarowych na obszarze pola drumlinowego „Zbójenko”. Centralne Archiwum Geologiczne Państwowego Instytutu Geologicznego, Warszawa.

Lamparski Z., 1972. Geneza form drumlinowych okolic Zbójna (Pojezierze Dobrzyńskie). Acta Geologica Polonica 22(1): 139-158. 
Lamparski Z., 1983. Plejstocen i jego podłoże w północnej części Środkowego Powiśla. Studia Geographica Polonica 76.

Lamparski Z., 1991. Loby lodowcowe w kopalnej i współczesnej rzeźbie Pojezierza Dobrzyńskiego. W: Geneza, litologia i stratygrafia osadów czwartorzędowych. UAM, Poznań, Seria Geografia 50: 105-115.

Lesemann J.-E., Piotrowski J.A., Wysota W., 2010. „Glacial curvilineations": New glacial landforms produced by longitudinal vortices in subglacial meltwaters flows. Geomorphology 120: 153-161.

Liberacki M., 1961. Drumlins near Zbójno. Guide-book of excursion. Pt 1. North Poland. VI INQUA Congress, Poland: 115-117.

Macioszczyk A., 1987. Hydrochemia. Wydawnictwa Geologiczne, Warszawa.

Major M., 2003. Zróżnicowanie przestrzenne cech fizykochemicznych wód powierzchniowych w wybranych oczkach wodnych na obszarze młodoglacjalnym (Pomorze zachodnie, górna Parsęta). W: W. Bochenek, E. Gil (red.), Zintegrowany Monitoring Środowiska Przyrodniczego w Polsce. Funkcjonowanie i monitoring geoekosystemów ze szczególnym uwzględnieniem zjawisk ekstremalnych. Biblioteka Monitoringu Środowiska: 173-187.

Major M., 2009. Charakter i funkcjonowanie zagłębień bezodpływowych w krajobrazie strefy młodoglacjalnej (Pomorze Zachodnie, górna Parsęta). Wydawnictwo Poznańskiego Towarzystwa Przyjaciół Nauk, Poznań.

Nechay W., 1927. Utwory lodowcowe Ziemi Dobrzyńskiej. Sprawozdania Polskiego Instytutu Geologicznego IV(1-2): 61-144.

Niewiarowski W., Olszewski A., Wysota W., 1995. The role of subglacial features in glacialmorphogenesis of the Kujawy Dobrzyń subphase area in the southern and eastern part of the Chełmno-Dobrzyń Lakeland. Quaternary Studies in Poland 13: 65-76.

Niewiarowski W., Wysota W., 1995. Zarys morfologii Pojezierza Dobrzyńskiego. W: Przewodnik wycieczki nr 3: Geomorfologia i hydrografia Pojezierza Brodnickiego i Dobrzyńskiego oraz osobliwości przyrodnicze parków krajobrazowych. 44 Zjazd PTG, Toruń: 41-45.

Noryśkiewicz A., Bienias D., Karasiewicz M.T., 2010. Historia roślinności i osadnictwa w północnej części ziemi dobrzyńskiej w świetle analizy pyłkowej profilu Zbójenko. W: A. Karczewski, A. Karczewska, M. Makohonienko, D. Makowiecki, E. Smolska, P. Szwarczewski (red.), Środowisko przyrodnicze, gospodarka, osadnictwo i kultura symboliczna w V w. p.n.e.-VII w. n.e. w dorzeczach Odry, Wisły i Niemna. Bogucki Wydawnictwo Naukowe, Poznań: 98-103.

Olszewski A., 1997. Drumlins of the northwestern Dobrzyń Moraine Plateau: location, structure and morphogenesis. Quaternary Studies in Poland 14: 71-83.

Olszewski A., 2000a. Stanowisko 3 - Obory (gm. Zbójno). Morfogeneza rzeźby terenu w okolicy Obór na tle poziomów glacjalnych i struktury drumlinu. W: P. Molewski, W. Wysota (red.), Dawne i współczesne systemy morfogenetyczne środkowej części Polski Północnej. V Zjazd Geomorfologów Polskich. Wydawnictwo Uniwersytetu Mikołaja Kopernika, Toruń: 38-48.

Olszewski A., 2000b. Stanowisko 2 - Wojnowo (gm. Zbójno). Rynny subglacjalne, kemy i terasa kemowa okolic Wojnowa we wschodniej części Zbójeńskiego Basenu Glacjalnego. W: P. Molewski, W. Wysota (red.), Dawne i współczesne systemy morfogenetyczne środkowej części Polski Północnej. V Zjazd Geomorfologów Polskich. Wydawnictwo Uniwersytetu Mikołaja Kopernika, Toruń: 30-38.

Olszewski A., 2000c. Stanowisko 1 - Zbójenko (gm. Zbójno). W stronę kwestii: drumliny czy drumlinoidy zbójeńskie? W: P. Molewski, W.
Wysota (red.), Dawne i współczesne systemy morfogenetyczne środkowej części Polski Północnej, V Zjazd Geomorfologów Pololskich. Wydawnictwo Uniwersytetu Mikołaja Kopernika, Toruń: 21-30.

Olszewski A., 2001a. Stop 1: Nowogród. Subglacial channels in the vicinity of Nowogród; drumlins, kames, and landscape polygenesis. W: J.A. Piotrowski, W. Wysota (red.), Drumlins: The unsolved problem. Field Excursion Guide Book, 6th International Drumlin Symposium. Wydawnictwo Uniwersytetu Mikołaja Kopernika, Toruń: 16-23.

Olszewski A., 2001b. Stop 1: Zbójenko. Drumlins of the northern (main) part of the Zbójno Glacial Basin. W: J.A. Piotrowski, W. Wysota (red.), Drumlins: The unsolved problem. Field Excursion Guide Book, 6th International Drumlin Symposium. Wydawnictwo Uniwersytetu Mikołaja Kopernika, Toruń: 24-30.

Podlasińska J., 2012. Zróżnicowanie i chemizm osadów małych zbiorników wodnych w krajobrazie młodoglacjalnym. Zachodniopomorski Uniwersytet Technologiczny, Szczecin.

Podlasiński M., 2013. Wpływ denudacji antropogenicznej na zróżnicowanie pokrywy glebowej i jej przestrzenna strukturę w rolniczym krajobrazie morenowym. Wydawnictwo Uczelniane Zachodniopomorskiego Uniwersytetu Technologicznego w Szczecinie.

Rudnicki J., 1979. Charakterystyka deformacji osadów drumlinowych okolic Zbójna. Biuletyn Geologiczny Uniwersytetu Warszawaskiego 23: $143-153$.

Sinkiewicz M., 1998. Rozwój denudacji antropogenicznej w środkowej części Polski Północnej. Wydawnictwo Uniwersytetu Mikołaja Kopernika, Toruń.

Smolska E., 2005. Znaczenie spłukiwania w modelowaniu stoków młodoglacjalnych (na przykładzie Pojezierza Suwalskiego). WGiSR UW Warszawa.

Stochlak J., 1996. Osady deluwialne - nieodłączny efekt procesu spłukiwania i propozycja ich podziału. Ogólnopolskie Sympozjum Naukowe nt. „Ochrona agroekosystemów zagrożonych erozją”. Prace Naukowe 2: 115-132.

Śnieżko Z., 1995. Ewolucja obszarów lessowych Wyżyn Polskich w czasie ostatnich 15000 lat. Wydawnictwo Uniwersytetu Śląskiego, Sosnowiec

Szpikowski J., 2012. Antropogeniczne przekształcenia rzeźby zlewni Perznicy w neoholocenie (Pojezierze Drawskie, dorzecze Parsęty). Wydawnictwo Naukowe Uniwersytetu im. Adama Mickiewicza, Poznań.

Świtoniak M., 2014. Use of soil profile truncation to estimate influence of accelerated erosion on soil cover transformation in young morainic landscapes, North-Eastern Poland. Catena 116: 173-184.

Twardy J., 2003. Cechy sedymentologiczne neoholoceńskich osadów stokowych na Wyżynie Łódzkiej i ich wartość interpretacyjna. Prace i Studia Geograficzne Wydziału Geografii i Studiów Regionalnych Uniwersytetu Warszawskiego 33: 25-44.

Wiśniewski E., 1965. Formy drumlinowe okolic Gniewu. Przegląd Geograficzny 37: 171-182.

Wysota W., 1999. Ice sheet maximum limit of the Vistulian Glaciation in the mid-eastern part of the Chełmno-Dobrzyń Lakeland, northern Poland. Geological Quarterly 43(2): 189-202.

Wysota W., 2007. Objaśnienia do szczegółowej mapy geologicznej Polski, arkusz Golub-Dobrzyń. Państwowy Instytut Geologiczny, Warszawa. 